\title{
Compositional Effect and Distance Sensitivity: Examining the Distance Elasticity in China and Indonesia Trade Activities
}

\author{
Putu Mahardika Adi Saputra
}

\begin{abstract}
This paper analyzes the change in distance elasticity of trade using bilateral trade data among China and Indonesia and their main trading partners. The empirical method used in this study derived from the gravity model that considers the effect of distance on trade activities behavior. Two causes of change in the elasticity of trade to distance will be exposed, i.e., the distance sensitivity effect (within industries) and the compositional effect (among industries). Specifically, this study would like to prove whether the distance sensitivity effect is more dominant than the compositional effect in explaining the change in distance elasticity of trade. By using four sub-periods and around two hundred industries involved, the result shows that the increase in the role of distance in trade heavily caused by the escalation of distance sensitivity effect in most industries.
\end{abstract}

Keywords: trade; gravity model; distance sensitivity effect; compositional effect

\begin{abstract}
Abstrak
Penelitian ini bertujuan untuk menganalisis perubahan koefisien elastisitas jarak perdagangan pada data aktivitas perdagangan bilateral diantara Tiongkok dan Indonesia serta negara-negara mitra dagang utama mereka. Metode empiris yang digunakan dalam studi ini diturunkan dari model gravitasi yang melibatkan peran dari jarak terhadap fluktuas aktivitas perdagangan. Dua komponen efek pengubah koefisien elastisitas jarak perdagangan akan dibahas secara mendalam, yaitu efek sensitifitas jarak (dalam industri) dan efek komposisional (antara industri). Secara khusus, studi ini berupaya untuk membuktikan apakah efek substitusi jarak berperan lebih dominan dibandingkan efek komposisional di dalam menjelaskan perubahan koefisien elastisitas jarak perdagangan. Dengan menggunakan empat sub-periode analisis dan sekitar dua ratus industri terpilih, ditemukan bahwa efek sensitivitas jarak terbukti lebih dominan di dalam menjelaskan kenaikan koefisien elastisitas jarak perdagangan pada sebagian besar industri yang dianalisis.
\end{abstract}

Kata Kunci: perdagangan; model gravitasi; efek sensitivitas jarak; efek komposisional

How to Cite:

Saputra, P. M. A. (2019). Compositional Effect and Distance Sensitivity: Examining the Distance Elasticity in China and Indonesia Trade Activities. Signifikan: Jurnal Ilmu Ekonomi. Vol. 8 (1): 79 - 92. doi: http://dx.doi. org/10.15408/sjie.v8i1.7469. 


\section{Introduction}

The critical role of trade cost for world trade activities has been revealed nowadays in much international economics works of literature. The study of that issue starting from a theoretical foundation concerning the impacts of distance towards trade activities thoroughly described by Anderson (1979). Until the estimation of trade cost that is averagely close to doubled production cost that described by Anderson and van Wincoop (2004). Trade cost defines the cost spent due to the distance taken to reach a market to sell products. Distance brings effects on trade cost since it relates to transport cost. The farther distance took, the more transport cost spends. Technology that had developed since the 1980s is expected to be able to improve the growth of trade and reduce transport cost; in fact, distance influences trade activities. By identifying the influence of distance on trade activities in a particular period, distance elasticity coefficients obtained from gravity regression compare.

Tinbergen (1962) and Pöyhönen (1963) introduces the idea of the Gravity model. It has an analogy with Newton's Gravity Law describing that there are two objects directly relate each other and have reversed relationship with distance. Deardorff (1998) believes that the gravity equation can explain the characteristics of international trade. The idea also supported by Gil-Pareja et al. (2007) and Giovannetti and Sanfilippo (2016) who believes that Gravity Model is consistent with any international trade basic theories, in which some other factors also considered, such as social, geography, politics, and culture. Moreover, Harrigan (1994) states that there are at least two different basic fundamental theories that can be related to the Gravity Model, i.e., Monopolistic Competition Model and Armington-HeckscherOhlin-Vanek Model. Gravity Model predicts that the bilateral trade value has both positive relationships with economic measurement of two countries measured by Gross Domestic Product per capita and negative relationship with trade cost.

The application of Gravity Model to investigate international trade has attracted many researchers, such as Eichengreen and Irwin (1995); Estevadeordal et al. (2002); LóPez-Córdova and Meissner (2003); Batra (2006)with statistically significant t-statistic often exceeding 50 in absolute value. Alternative measures of gross national product (GNP; Accominotti and Flandreau (2008)for it rested on bilateral negotiations and most-favored-nation clauses.With the help of new data on international trade (the Ricardo database; Disdier and Head (2008); Mitchener and Weidenmier (2008); Jacks et al. (2010); Saputra (2014); and Kunze (2016). They mention some reasons why distance could correlate and influence the bilateral trade, among others: First, distance is a proxy of transaction cost. Second, the distance can indicate the time required to send products. Third, distance correlates with disbursement cost for trading. Fourth, the increasing distance elasticity happens from year to year. Fifth, distance brings negative impacts to bilateral trade; and (vi) distance can correlate with culture, in which the farther distance took, the more different culture find so that additional cost (called as negotiation cost) to solve communication problems will be higher.

Distance also has been connected to economic conflicts (Chang et al., 2004). Distance gives both direct and indirect effects on conflicts. As the direct effect, distance reduces partnership and conflicts between two countries since transport cost and trade cost increase; 
on the other hand, distance indirectly reduces trade and partnership as well as increases conflicts.

Frankel et al. (1997) find that a 10\% increase in distance variable led $4 \%$ decreasing on trade in the 1960s as well as 7\% in the 1990s. The study, furthermore, reveals that the development of the distance elasticity coefficient stays the same from the 20th century until now. Meanwhile, using meta-analysis in estimating distance coefficient, the increasing of the impact of distance towards trade is $20 \%$ since 1965 (Disdier \& Head, 2008). Brun et al. (2005) estimates panel Gravity Model for 1962-1996 and finds that the distance coefficient increases about $11 \%$ for the last 35 years. The same results also exposed by Coe et al. (2007).

The paper is conceptually related to the literature on analyzing the evolution of distance elasticity of trade as introduced by Berthelon \& Freund (2008). According to them, two parts could make the distance elasticity to change. The first part elucidates a change as an effect of the movement of trade composition among industries (compositional effect), and the second one describes a change as an effect of the development of distance sensitivity in industries (distance-sensitivity effect). This study will contribute to the literature through its provision on a better understanding in detecting whether the role of distance in influencing trade activity is more dominantly explained by distance sensitivity effect or compositional effect, especially for the bilateral trade data from two major markets in East Asia region, i.e., China and Indonesia. To the best of author knowledge, this is the first work that implements those two parts (decomposition effects) on China and Indonesia bilateral dataset.

The result of this study reveals that the role of distance in trade dominantly is triggered by the distance sensitivity effect that increases in major industries. On other hands, although the compositional effect appears, its figure is lower than distance-sensitivity effect.

\section{Methods}

This study focuses on trade activities conducted by two big countries in Asia positioned as reporting countries, namely China and Indonesia. In order to analyze their trade activities, their primary trading partner countries are involved in the analysis. The partner countries are Malaysia, Thailand, Singapore, Philippine, Japan, Korea, the United States of America, Germany, and the Netherlands. The countries' import data using in representing the trade activities behavior, meanwhile, distance (presented by $\mathrm{km}$ ) measures how far the capital city of reporting countries is from each capital city of its partner countries.

The analysis will be done for 1985 to 2005 data by dividing them into four subperiods, which are: (i) total period (1985-2005); (ii) period 1985-1989; (iii) period 19901999; and (iv) period 2000-2005. Data are summarizing in 4-digit SITC Revision 2 issued by UN COMTRADE. The data include more than 200 types of industries.

In order to analyze the effect of distance towards trade activities, the causes of changes on distance elasticity are decomposing into two parts: (i) compositional effect; and (ii) distancesensitivity effect (Berthelon \& Freund, 2008). According to Dee et al. (2008), compositional effect defines as an effect that brings trade move towards more distance sensitive industries, 
and the distance-sensitivity effect is an effect that makes industries shift towards distance sensitivity practice.

Distance elasticity varies for each industry, and its role to trade activities can illustrate through the gravity equation of industry that presented as follows:

$$
x_{i j k}=A_{k} \frac{y_{i}^{a} y_{j}^{b}}{D_{i j}^{c k}}
$$

The equation describes that $x_{i j k}$ is the trade flow from country $i$ to country $j$ for product $k$. Meanwhile, $A_{k}$ is a constant representing how important a particular product is in consumption activities and variation based on the product. If $y_{i}$ represents the income of country $i$, then $y_{j}$ does the income of country $j$. The last but not least, $c k$ is distance elasticity of a particular product as well as $D_{i j}$ is how far country $i$ is from country $j$. The summation of Equation (1) for all products will obtain total trade flow from country $i$ and country $j\left(X_{i j}=\sum_{k} x_{i j k}\right)$.

$$
X_{i j}=y_{i}^{a} y_{j}^{b} \sum_{k} \frac{A_{k}}{D_{i j}^{c k}}
$$

Next, the logarithmic form of aggregate bilateral trade is written as the function of income and distance as it is showed below.

$$
\ln X_{i j}=a \ln y_{i}+b \ln y_{j}+\ln \left(\sum_{k} \frac{A_{k}}{D_{i j}^{c k}}\right)
$$

The gravity equation estimated with aggregate data, meanwhile, is:

$$
\ln X_{i j}=K+a \ln y_{i}+b \ln y_{j}+c \ln D_{i j}+\varepsilon_{i j}
$$

In order to decompose the changes of distance elasticity into two components have been mentioned above, $c k$ firstly is defined as distance elasticity from product or industry $k$. $c$ is then formulated as follows:

$$
c=\sum_{k} s k \cdot c k
$$

If $s_{k}$ is share from industry $k$ in the total of trade flow, the change of distance coefficient is:

$$
\Delta c_{t}=\sum_{k} \Delta s k c k+\sum_{k} s k \Delta c k
$$

There are two right hand side components of Equation (6), i.e., compositional effect and distance-sensitivity, respectively. The calculation of distance elasticity is utilized in each industry for all periods to obtain $c k$; meanwhile, the comparison between the value of $c$ in the first period and which in the second period in order to obtain the value of $\Delta c k$. Compositional effect is measured by knowing distance elasticity of each industry $(c k)$ for all periods first, and that distance elasticity is estimated by the following regression equation ( $k$ subscript is dropped).

$$
\ln X_{i j}=a_{i}+a_{j}+c \ln D_{i j}+\varepsilon_{i j}
$$


The notation of " $a$ " describes the fixed-effect of countries and products, $\varepsilon_{i j}$ is error term for i.i.d. The estimation of Equation (7) did by grouping panel data into two. The first one is aggregate panel data using all data found from 1985-2005, and the other one is periodic panel data in which data are grouped again into three parts based on a particular period (period 1985-1989, period 1990-1999, and period 2000-2005). According to Berthelon and Freund (2008), the distance coefficient is shown by the elasticity of trade to distance, while the compositional effect measured by using a weighted-average distance coefficient where the value of weight is formulated based on the changes of the average shares of industries on trade in the considered periods.. On the other hand, in order to estimate the distancesensitivity effect, the changes on distance elasticity $(\Delta c k)$ need to be measured; consequently, the distance coefficient in Equation (7) must be time varying:

$$
\Delta \ln X_{i j}=b_{i}+b_{j}+z \ln D_{i j}+v_{i j}
$$

$b_{i}$ and $b_{j}$ means $\left(a_{i t}-a_{i t-1}\right)$ and $\left(a_{j t}-a_{j t-1}\right)$ respectively; then $z$ denotes $\left(c_{t}-c_{t-1}\right)$. The $z$ is then utilized as an estimator of $\Delta c k$ in which the value of coefficient is interpreted as the percentage of changes on the annual growth of trade for a percentage change on distance.

\section{Result and Discussion}

\section{The Description of Indonesian Trade Activities}

Describing the characteristics of import trade activities conducted by Indonesia, three tables present in order to briefly explain the share value of import trade activities between a reporter country, which is in this case Indonesia, and its partner countries. Indonesian partner countries group into three groups. The first group consists of four ASEAN countries: Malaysia (Mys), Thailand (Tha), Singapore (Sgp), and Philippines (Phl). Meanwhile, three East Asian countries, Japan (Jpn), Korea (Kor), and China (Chn) belong to the second group. A next group is a group of Non-Asian countries consisting of the United States of America (USA), Germany (Deu), and Netherlands (NLD).

Table 1. The Rank of Total Share of Indonesia's Top 10 Products for Each ASEAN Market towards World (based on Import Value, showed by code)

\begin{tabular}{ccccc}
\hline \multirow{2}{*}{ Rank } & Idn-Mys & Idn-Tha & Idn-Sgp & Idn-Phl \\
\cline { 2 - 5 } & Code & Code & Code & Code \\
\hline 1 & 3330 & 3330 & 3343 & 7849 \\
2 & 5121 & 7853 & 3344 & 5121 \\
3 & 7272 & 7849 & 7938 & 2231 \\
4 & 7415 & 1110 & 7239 & 7493 \\
6 & 7284 & 7783 & 5121 & 7244 \\
7 & 7649 & 7415 & 5989 & 5989 \\
8 & 7416 & 5989 & 7649 & 6649 \\
9 & 7849 & 7493 & 7234 & 0223 \\
10 & 3343 & 0470 & 7721 & 0980 \\
\hline
\end{tabular}

Source: processed secondary data (UN Comtrade, 1985-2005)

Notes: Idn: Indonesia, Mys: Malaysia, Tha: Thailand, Sgp: Singapore, and Phl: Philippines 
Table 1 and Table 3 show the top 10 ranks of import share commodities Indonesia conducts with its main Asian partner countries from 1985 to 2005. The highest rank commodity that imported by Indonesia from Malaysia market is a product with code SITC 3330 (Crude petroleum and oils obtained from bituminous materials). The related product also reaches the first position in the rank of Indonesia's import from China and Thailand. Meanwhile, Singapore and Philippine market put a product with code SITC 3343 (Gas oil) and SITC 7849 (Other parts and accessories, for vehicles of headings 722, 781-783) in the highest rank, respectively.

Table 2. Total Share of Indonesia's Top 10 Products for Each ASEAN Market towards World (\%, import value)

\begin{tabular}{ccccc}
\hline \multirow{2}{*}{ Rank } & Idn-Mys & Idn-Tha & Idn-Sgp & Idn-Phl \\
\cline { 2 - 4 } & Share & Share & Share & Share \\
\hline 1 & 0.06923 & 0.01424 & 0.11688 & 0.00217 \\
2 & 0.00679 & 0.00555 & 0.05009 & 0.00860 \\
3 & 0.00668 & 0.00540 & 0.03073 & 0.00086 \\
4 & 0.00430 & 0.00309 & 0.01698 & 0.00085 \\
5 & 0.00407 & 0.00307 & 0.01552 & 0.00051 \\
6 & 0.00331 & 0.00260 & 0.01057 & 0.00030 \\
8 & 0.00198 & 0.00254 & 0.00809 & 0.00029 \\
9 & 0.00195 & 0.00199 & 0.00654 & 0.00020 \\
10 & 0.00190 & 0.00182 & 0.00625 & 0.00020 \\
& 0.00146 & 0.00154 & 0.00598 & 0.00018 \\
\hline
\end{tabular}

Source: processed secondary data (UN Comtrade, 1985-2005)

Notes: Idn: Indonesia, Mys: Malaysia, Tha: Thailand, Sgp: Singapore, and Phl: Philippines

Table 2 is used to explain Table 1 by presenting the percentage value of each share value from each commodity towards world import activities. According to Table 2, the most significant share of Indonesia's import products from all ASEAN countries is a product with code SITC 3343 from Singapore (0.12\%).

Table 3. Total Share of Indonesia's Top 10 Products for Each East Asian Market towards World (\%, import value)

\begin{tabular}{ccccccc}
\hline \multirow{2}{*}{ Rank } & \multicolumn{2}{c}{ Idn-Jpn } & \multicolumn{2}{c}{ Idn-Kor } & \multicolumn{2}{c}{ Idn-Chn } \\
\cline { 2 - 6 } & Code & Share (\%) & Code & Share (\%) & Code & Share (\%) \\
\hline 1 & 3330 & 0.30317 & 3330 & 0.02237 & 3330 & 0.03915 \\
2 & 5121 & 0.09874 & 7853 & 0.01096 & 2222 & 0.02926 \\
3 & 7272 & 0.06365 & 7849 & 0.00802 & 1212 & 0.00823 \\
4 & 7415 & 0.05936 & 1110 & 0.00775 & 7853 & 0.00629 \\
5 & 7284 & 0.05411 & 7783 & 0.00730 & 6522 & 0.00581 \\
6 & 7649 & 0.05032 & 7415 & 0.00692 & 6716 & 0.00579 \\
7 & 7416 & 0.03219 & 5989 & 0.00689 & 7284 & 0.00557 \\
8 & 7849 & 0.02691 & 7493 & 0.00646 & 7244 & 0.00456 \\
9 & 3343 & 0.02550 & 470 & 0.00581 & 8942 & 0.00406 \\
10 & 7938 & 0.02429 & 7492 & 0.00567 & 7649 & 0.00363 \\
\hline
\end{tabular}

Source: processed secondary data (UN Comtrade, 1985-2005)

Notes: Idn: Indonesia, Jpn: Japan, Kor: South Korea, and Chn: China 
Table 3 describes that SITC 3330 (Crude petroleum and oils obtained from bituminous materials) takes the first place as the most imported product by Indonesia from non-Asian main partner countries. Indonesia imported a product with code ISIC 3330 (Crude petroleum and oils obtained from bituminous materials) from Japan as much as $0.3 \%$ of the total of world import activities for all commodities described on SITC Rev 2.

Table 4. Total Share of Indonesia's Top 10 Products for Each Non-Asian Main Market towards World (\%, import value)

\begin{tabular}{ccccccc}
\hline \multirow{2}{*}{ Rank } & \multicolumn{2}{c}{ Idn-Usa } & \multicolumn{2}{c}{ Idn-Deu } & \multicolumn{2}{c}{ Idn-NId } \\
\cline { 2 - 7 } & Code & Share (\%) & Code & Share (\%) & Code & Share (\%) \\
\hline 1 & 7239 & 0.08205 & 7284 & 0.03258 & 7938 & 0.00670 \\
2 & 7938 & 0.05843 & 7244 & 0.03100 & 0980 & 0.00429 \\
3 & 2222 & 0.05215 & 7721 & 0.01766 & 7284 & 0.00426 \\
4 & 7234 & 0.02808 & 7649 & 0.01581 & 3343 & 0.00283 \\
5 & 5989 & 0.02807 & 7452 & 0.01154 & 5989 & 0.00269 \\
6 & 0412 & 0.02591 & 7849 & 0.01098 & 7649 & 0.00267 \\
7 & 7492 & 0.01929 & 7643 & 0.01034 & 7416 & 0.00239 \\
8 & 7416 & 0.01774 & 5989 & 0.00880 & 7721 & 0.00235 \\
9 & 7649 & 0.01675 & 7247 & 0.00709 & 7782 & 0.00196 \\
10 & 0819 & 0.01639 & 9510 & 0.00670 & 5417 & 0.00188 \\
\hline
\end{tabular}

Source: processed secondary data (UN Comtrade, 1985-2005)

Notes: Idn: Indonesia, USA: United States of America, Deu: Germany, and Nld: Netherlands

Table 4 explains Indonesia's import share from the non-Asian partner countries, which are the United States of America, Germany, and the Netherlands. Unlike what the previous tables show, SITC 3330 (Crude petroleum and oils obtained from bituminous materials) is not a dominant commodity anymore in non-Asian countries. The highest rank of Indonesia's import commodity from the United States of America is positioned by SITC 7239 (Parts, of machinery and equipment of headings 72341 to 72346 ) with the value of import share towards the world as much as $0.08 \%$. On the other hand, SITC 7284 (Machinery for specialized industries and parts thereof) becomes top Indonesia's import commodity from Germany, and SITC 7938 (Tugs, special purpose vessels, and floating structures) that is $0.007 \%$ takes the first rank of Indonesia's import share commodity from the Netherlands.

Table 5. The Rank of Total Share of China's Top 10 Products for Each ASEAN Market towards World (based on Import Value, showed by code)

\begin{tabular}{|c|c|c|c|c|c|}
\hline \multirow{2}{*}{ Rank } & Chn-Idn & Chn-Mys & Chn-Sgp & Chn-Tha & Chn-Phl \\
\hline & Code & Code & Code & Code & Code \\
\hline 1 & 3330 & 7599 & 3343 & 7599 & 7599 \\
\hline 2 & 6342 & 3330 & 7599 & 3330 & 7649 \\
\hline 3 & 6344 & 6342 & 7649 & 7649 & 8710 \\
\hline 4 & 2483 & 7649 & 0251 & 0251 & 0251 \\
\hline 5 & 0223 & 2483 & 7284 & 2483 & 7788 \\
\hline 6 & 7849 & 5121 & 8983 & 7491 & 7591 \\
\hline 7 & 7599 & 7788 & 7414 & 7788 & 6342 \\
\hline 8 & 5121 & 7768 & 7722 & 7712 & 7712 \\
\hline 9 & 6513 & 6344 & 5121 & 7722 & 7768 \\
\hline 10 & 7649 & 7722 & 7788 & 0819 & 7722 \\
\hline
\end{tabular}

Source: processed secondary data (UNComtrade, 1985-2005)

Notes: Chn: China, Idn: Indonesia, Mys: Malaysia, Tha: Thailand, Sgp: Singapore, and Phl: Philippines 


\section{The Description of Chinese Trade Activities}

This part describes the import trade activities done by China. In line with Indonesia, China has three groups of partner countries: ASEAN countries (Indonesia, Malaysia, Singapore, Thailand, Philippine), East Asian countries (Korea and Japan), and non-Asian countries (the United States of America, Germany, Netherlands).

Table 5 describes the top 10 of China's import share commodities with its partner countries from 1985 to 2005. The first ranks of import commodities from Indonesia are products with code SITC 3330 (Crude petroleum and oils obtained from bituminous materials). SITC 7599 (Parts, nes of and accessories for machines of headings 7512 and 752), meanwhile, becomes top China's import commodity from Malaysia, Thailand, and the Philippines.

Table 6. Total share of China's Top 10 Products for Each ASEAN Market towards World (\%)

\begin{tabular}{cccccc}
\hline \multirow{2}{*}{ Rank } & Chn-Idn & Chn-Mys & Chn-Sgp & Chn-Tha & Chn-Phl \\
\cline { 2 - 5 } & Share & Share & Share & Share & Share \\
\hline 1 & 0.21722 & 0.05736 & 0.12080 & 0.08511 & 0.02059 \\
2 & 0.12071 & 0.04194 & 0.07933 & 0.01805 & 0.01138 \\
3 & 0.03276 & 0.04110 & 0.04019 & 0.01758 & 0.00913 \\
4 & 0.03170 & 0.02908 & 0.02844 & 0.01440 & 0.00711 \\
5 & 0.01640 & 0.01989 & 0.01944 & 0.01021 & 0.00491 \\
6 & 0.01416 & 0.01553 & 0.01885 & 0.00691 & 0.00337 \\
7 & 0.01206 & 0.01317 & 0.01883 & 0.00621 & 0.00312 \\
8 & 0.01027 & 0.00929 & 0.01675 & 0.00582 & 0.00283 \\
9 & 0.00892 & 0.00925 & 0.01248 & 0.00478 & 0.00181 \\
10 & 0.00751 & 0.00741 & 0.01240 & 0.00423 & 0.00163 \\
\hline
\end{tabular}

Source: processed secondary data (UN Comtrade, 1985-2005)

Notes: Chn: China, Idn: Indonesia, Mys: Malaysia, Tha: Thailand, Sgp: Singapore, and Phl: Philippines

Furthermore, Table 6 shows the percentage value of each share value from each commodity towards world import activities by referring to Table 5. A commodity coded SITC 7599 (Parts, nes of and accessories for machines of headings 7512 and 752) is the primary import commodity of China since it reaches $0.06 \%$ for each partner country. Table 7 is presented to describe the condition of China's import share commodities from the second group of partner countries: Korea and Japan. Reaching world import share value as much as $0.26 \%$, SITC 8710 (Optical instruments and apparatus) becomes the first rank of China's import share commodity from Korea. A commodity coded SITC 0223 (Milk and cream fresh, not concentrated or sweetened) then becomes the first rank of China's import share commodity from Japan reaching $0.64 \%$ of the total of world import activities for all commodities described on SITC Rev 2. 
Putu Mahardika Adi Saputra Compositional Effect and Distance Sensitivity

Table 7. The Total Share of China's Top 10 Products for Two East Asian Countries' Market towards World (\%, import value)

\begin{tabular}{ccccc}
\hline \multirow{2}{*}{ Rank } & \multicolumn{2}{c}{ Chn-Kor } & \multicolumn{2}{c}{ Chn-Jpn } \\
\cline { 2 - 5 } & Code & Share & Code & Share \\
\hline 1 & 8710 & 0.26756 & 0223 & 0.63509 \\
2 & 7649 & 0.18554 & 7284 & 0.56461 \\
3 & 7643 & 0.08358 & 7649 & 0.43381 \\
4 & 7284 & 0.08290 & 7599 & 0.23576 \\
5 & 7599 & 0.07195 & 7788 & 0.23039 \\
6 & 7788 & 0.05279 & 7721 & 0.21181 \\
7 & 7768 & 0.04527 & 7849 & 0.19925 \\
8 & 7849 & 0.04348 & 8710 & 0.14096 \\
9 & 7722 & 0.03309 & 7245 & 0.12847 \\
10 & 7721 & 0.03271 & 7768 & 0.12572 \\
\hline
\end{tabular}

Source: processed secondary data (UN Comtrade, 1985-2005)

Notes: Chn: China, Kor: South Korea, and Jpn: Japan

Table 8 represents the condition of import shares of China from the United States of America, Germany, and the Netherlands. Regarding import activities with the United States of America, a product coded SITC 0223 (Milk and cream fresh, not concentrated or sweetened) positions itself in the first rank of China's import share commodity as much as $0.27 \%$. The highest import commodity China gains from Germany is SITC 7284 (Machinery for specialized industries and parts thereof, nes), and it is $0.24 \%$. Besides, gaining the value of world import share as much as $0.028 \%$, SITC 7284 (Machinery for specialized industries and parts thereof, nes) takes the top position of China's import share commodity from the Netherlands.

Table 8. The Total share of China's Top 10 Products for Non-Asian Countries' Markets towards World (\%)

\begin{tabular}{ccccccc}
\hline \multirow{2}{*}{ Rank } & \multicolumn{2}{c}{ Chn-Usa } & \multicolumn{2}{c}{ Chn-Deu } & \multicolumn{2}{c}{ Chn-NId } \\
\cline { 2 - 7 } & Code & Share & Code & Share & Code & Share \\
\hline 1 & 0223 & 0.26871 & 7284 & 0.24495 & 7284 & 0.02843 \\
2 & 0251 & 0.23762 & 7849 & 0.19399 & 0251 & 0.01419 \\
3 & 7284 & 0.20378 & 7721 & 0.09112 & 7649 & 0.00858 \\
4 & 2222 & 0.19201 & 7244 & 0.06456 & 8813 & 0.00831 \\
5 & 7649 & 0.11496 & 7649 & 0.04819 & 7938 & 0.00776 \\
6 & 8748 & 0.10205 & 7452 & 0.04454 & 7272 & 0.00633 \\
7 & 7599 & 0.09064 & 7245 & 0.04083 & 7768 & 0.00536 \\
8 & 7643 & 0.06643 & 7372 & 0.03818 & 7721 & 0.00522 \\
9 & 7721 & 0.05858 & 7416 & 0.03013 & 7742 & 0.00512 \\
10 & 8742 & 0.05240 & 8742 & 0.02834 & 7416 & 0.00330 \\
\hline
\end{tabular}

Source: processed secondary data (UN Comtrade, 1985-2005)

Notes: Chn: China, Usa: United State of America, Deu: Germany, and Nld: Netherlands 


\section{The Description of Main Import Products of Indonesia and China}

Two main import products owned by both Indonesia and China during the total research period then described in this part. As described by the data, the commodity with code 7849 (Other parts and accessories, for vehicles of headings 722, 781-783) is a commodity with the highest aggregate import share in Indonesia, and so is 7284 (Machinery for specialized industries and parts thereof, nes) in China. Aggregately, those commodities positioned in the highest rank belong to top 10 products presented by the import tables of each reporter country.

Indonesia's highest aggregate import share commodity, 7849 (Other parts and accessories, for vehicles of headings 722,781-783), has Malaysia, Thailand, and Philippine be partner countries for import group from ASEAN; meanwhile, Japan and Korea are partner countries from East Asian countries as well as Germany is from non-Asia country. Next, 3330 (Crude petroleum and oils obtained from bituminous materials) which is in the second rank of Indonesia's highest aggregate import share positions itself in top 10 import share of five partner countries that are Malaysia, Thailand, Japan, Korea, and China.

The commodity with code 7284 (Machinery for specialized industries and parts thereof, nes) identified as China's highest aggregate import commodity from its partner countries. The partner countries specifically are Singapore, Japan, Korea, the United States of America, Germany, and the Netherlands. The commodity 7649 (Parts, nes of and accessories for apparatus falling in heading 76) positioned in the second rank of China's highest aggregate import. It becomes the top 10 of China's import commodity from the partner countries, except the United States of America and the Netherlands.

\section{Distance-Sensitivity Effect and Composition Effect}

Regression method firstly is applied to measure the distance elasticity of each industry from 1985 through 2005. The changes in the average value of the distance coefficient after being grouped into two effect such as distance-sensitivity effect and compositional effect for each considered period shows in Table 9. There are three periods presented in Table 9: Total period of 1985-2005, Sub period of 1990-1999, and Sub period of 2000-2005. The results of sub-period 1985-1989 cannot be presented in the table since there is not enough data to analyze. All periods overall tend to show that the growth of trades moves to nearer distance proved by distance coefficient increasing with magnitude $-1.56 \mathrm{E}-07$ in the total period of 1985-2005 (Line 1, Column 3). That condition is in line with the condition in the sub-period of 1990-1999 as well as the sub-period of 2000-2005 (Line 2 and 3, Column 3). 
Putu Mahardika Adi Saputra

Compositional Effect and Distance Sensitivity

Table 9. The Decomposition Results of Distance Coefficient: Distance-Sensitivity Effect and Compositional Effect

\begin{tabular}{cccc}
\hline & $\begin{array}{c}(1) \\
\text { Distance-Sensitivity } \\
\text { Effect }\end{array}$ & $\begin{array}{c}\text { (2) } \\
\text { Compositional } \\
\text { Effect }\end{array}$ & Total \\
\hline $\begin{array}{c}\text { Total Period } \\
(1985-2005)\end{array}$ & $-8.90242 \mathrm{E}-08$ & $-6.74602 \mathrm{E}-08$ & $-1.56484 \mathrm{E}-07$ \\
$\begin{array}{c}\text { Sub Period } \\
(1990-1999)\end{array}$ & $-5.17308 \mathrm{E}-07$ & $-2.7431 \mathrm{E}-08$ & $-5.44739 \mathrm{E}-07$ \\
$\begin{array}{c}\text { Sub Period } \\
(2000-2005)\end{array}$ & $-1.67626 \mathrm{E}-06$ & $-1.87772 \mathrm{E}-07$ & $-1.9 \mathrm{E}-06$ \\
\hline
\end{tabular}

Source: processed data

In general, negative coefficients show for the effect of distance in all periods considered on the analysis. This result indicates that bilateral trade activity will increase for a closer distance of the two countries involved. The sub period of 2000-2005 was noted to have the greatest distance-sensitivity effect. It means that the activity of trade becomes more sensitive to the distance change in those periods.

On the other hand, the compositional effect in this study is found to be lesser than the distance-sensitivity effect. This result implies that any significant change in the effect of distance does not originate from the compositional effect. Based on the result found, this study supports the conclusion of Berthelon and Freund (2008).

Table 10. The Value of Distance Coefficient on Different Samples

\begin{tabular}{|c|c|c|c|}
\hline & (1) & (2) & (3) \\
\hline & $1985-2005$ & 1990-1999 & $2000-2005$ \\
\hline \multicolumn{4}{|l|}{ A. Regression with } \\
\hline aggregate data & -0.212457 & -0.251328 & -0.581083 \\
\hline Distance Coefficient & $(0.176)$ & (0.154) & $(0.084)$ \\
\hline Total of Observation & 399 & 200 & 118 \\
\hline \multicolumn{4}{|l|}{ B. Regression with } \\
\hline $\begin{array}{l}\text { industrial data } \\
\text { Measured average distance coefficient }\end{array}$ & $-8.14851 E-07$ & $-6.45458 \mathrm{E}-07$ & $-1.60285 E-06$ \\
\hline
\end{tabular}

Source: processed data

Meanwhile, Table 10 shows the result of an analysis on how close the characteristic of measured average distance coefficient is to that of aggregate data distance coefficient. If Panel A presents average distance coefficient in the total period of 1985-2005, sub-period of 19901999, and sub-period of 2000-2005, Panel B presents measured average coefficient from industrial data regression. Both regression specifications showed by Table 10 are different since coefficients from industrial data consider different country-fixed effect for each industry; on the other hand, aggregate data obtain only one coefficient for each period of country-time. 
After each industry's distance coefficient in each period measured with its trade contribution, then the result will be obtained. Measured average coefficient showed by industrial data in Panel B looks smaller than distance coefficients showed by aggregate data in Panel A in each period. However, their general effects are found to be consistent with the theory and previous research, i.e., contrary. The results imply that the importance of distance becomes increase for two consecutive periods (1990-1999 to 2000-2005).

\section{Conclusion}

This research is proving changes of distance effect on trade activities. This study analyzes the bilateral trade data between China and Indonesia. The changes in distance coefficients on trade activities grouping into two effects that are distance-sensitivity effect and compositional effect. Besides, this study proves whether or not the distance-sensitivity effect is a more dominating role on generally influencing the changes in distance coefficient than a compositional one.

Analyzing regression results by utilizing aggregate data (bilateral), the finding of this study reveals that the role of distance has become important since 1980' due to the increase of distance sensitivity effect in most big industries. The compositional effect is smaller than the distance sensitivity effect. Due to the distance coefficient appears to be getting more substantial in the final period of the study (2000-2005), it can conclude that the movement of trading activity becomes increasingly sensitive to distance changes. This result indicates that trade costs have tended to change in some industries which then cause distance becomes increasingly essential. In this case, industries should put their attention on the effect of high trade costs, especially on the initial trade costs, e.g., transport and tariffs for their products that produced and traded from time to time. Lastly, this study generally does not find out the existence of the "death of distance" in the analyzed case.

\section{References}

Accominotti, O., \& Flandreau, M. (2008). Bilateral Treaties and the Most-Favored-Nation Clause: The Myth of Trade Liberalization in the Nineteenth Century. World Politics, 60(2), 147-188.

Anderson, J. E. (1979). A Theoretical Foundation for the Gravity Equation. The American Economic Review, 69(1), 106-116.

Anderson, J. E., \& van Wincoop, E. (2004). Trade Costs. Journal of Economic Literature, 42(3), 691-751.

Batra, A. (2006). India’s Global Trade Potential: The Gravity Model Approach. Global Economic Review, 35(3), 327-361.

Berthelon, M., \& Freund, C. (2008). On the conservation of distance in international trade. Journal of International Economics, 75(2), 310-320.

Brun, J.-F., Carrere, C., Guillaumont, P., \& de Melo, J. (2005). Has Distance Died? Evidence from a Panel Gravity Model. The World Bank Economic Review, 19(1), 99-120. 
Chang, Y.-C., Polachek, S. W., \& Robst, J. (2004). Conflict and trade: the relationship between geographic distance and international interactions. The Journal of SocioEconomics, 33(4), 491-509.

Coe, N. M., Kelly, P. F., \& Yeung, H. W.-C. (2007). Economic Geography : A Contemporary Introduction. Malden, USA: Wiley-Blackwell.

Deardorff, A. V. (1998). Determinants of Bilateral Trade: Does Gravity Work in a Neoclassical World? In J. A. Frankel (Ed.), The Regionalization of the World Economy (p. 296). Chicago, USA: University of Chicago Press.

Dee, P., Findlay, C., \& Pomfret, R. (2008). Trade Facilitation: What, Why, How, Where and When? In D. H. Brooks \& J. Menon (Eds.), Infrastructure and Trade in Asia (p. 240). Northampton, USA: Edward Elgar.

Disdier, A.-C., \& Head, K. (2008). The Puzzling Persistence of the Distance Effect on Bilateral Trade. Review of Economics and Statistics, 90(1), 37-48.

Eichengreen, B., \& Irwin, D. A. (1995). Trade blocs, currency blocs and the reorientation of world trade in the 1930s. Journal of International Economics, 38(1-2), 1-24.

Estevadeordal, A., Frantz, B., \& Taylor, A. M. (2002). The Rise and Fall of World Trade, 18701939. NBER Working Papers. National Bureau of Economic Research, Inc. Retrieved from https://ideas.repec.org/p/nbr/nberwo/9318.html

Frankel, J. A., Stein, E., \& Wei, S.-J. (1997). Regional trading blocs in the world economic system. Washington, DC: Institute for International Economics. Retrieved from https://piie. com/bookstore/regional-trading-blocs-world-economic-system

Gil-Pareja, S., Llorca-Vivero, R., \& Martínez-Serrano, J. A. (2007). The Effect of EMU on Tourism. Review of International Economics, 15(2), 302-312.

Giovannetti, G., \& Sanfilippo, M. (2016). Do Chinese Exports Crowd-out African Goods? An Econometric Analysis by Country and Sector. In S. Henson \& O. F. Yap (Eds.), The Power of the Chinese Dragon (pp. 10-41). London, UK: Palgrave Macmillan.

Harrigan, J. (1994). Scale Economies and the Volume of Trade. The Review of Economics and Statistics, 76(2), 321-328.

Jacks, D. S., Meissner, C. M., \& Novy, D. (2010). Trade costs in the first wave of globalization. Explorations in Economic History, 47(2), 127-141.

Kunze, K. (2016). Empirical analysis of innovation and trade in Europe: a gravity model approach. International Journal of Trade and Global Markets, 9(3), 197-211.

LóPez-Córdova, J. E., \& Meissner, C. M. (2003). Exchange-Rate Regimes and International Trade: Evidence from the Classical Gold Standard Era. American Economic Review, 93(1), 344-353.

Mitchener, K. J., \& Weidenmier, M. (2008). Trade and Empire. The Economic Journal, 118(533), 1805-1834.

Pöyhönen, P. (1963). A Tentative Model for the Volume of Trade between Countries. Weltwirtschaftliches Archiv. Springer. 
Saputra, P. M. A. (2014). The Effect of Regionalism and Infrastructure on Bilateral Trade: An Augmented Gravity Analysis for ASEAN. International Journal of Economics and Finance, 6(3), 88-95.

Tinbergen, J. (1962). Shaping the World Economy; Suggestions for an International Economic Policy. New York: Twentieth Century Fund. Retrieved from https://repub.eur.nl/ $\mathrm{pub} / 16826$ 